\title{
A FRAMEWORK FOR UNDERSTANDING THE ROLE OF CULTURE IN ENTREPRENEURSHIP
}

\author{
B Urban, Department of Entrepreneurship, Faculty of Management, University of Johannesburg
}

\begin{abstract}
Purpose: Synthesising research findings on business regulations, culture, self, and entrepreneurship, this article provides a broad overview of the potential patterns of relationships between cultural values, personal and contextual factors, and entrepreneurial outcomes. Theories of entrepreneurship where either environmental or personality variables have been specified as unique predictors of entrepreneurship are investigated to determine whether they capture the complexity of entrepreneurial action that encompasses the interaction of environmental, cognitive, and behavioural variables. Emphasis is also placed on the South African business environment, where business regulations that may enhance or constrain new business activity are analysed.
\end{abstract}

Design/Methodology/Approach: Building on previous conceptualisations and empirical findings, the article identifies salient antecedents and consequences of venture creation from established literature. A framework is then proposed, building on previous findings to approach the interaction between the multiple interacting influences on entrepreneurship more systematically.

Findings: Principal literature reviews indicate that, despite SA's apparent favourable regulatory environment, low entrepreneurial activity persists, and understanding the interplay between culture, self, context and entrepreneurship remains imperative for policymakers and practitioners. In the proposed model, cultural values affect the perception of an individual resulting in key entrepreneurial outcomes; culture is depicted as a moderator in the relationship between contextual factors (business regulations) and entrepreneurial outcomes, and acts as a catalyst rather than a causal agent of entrepreneurial outcomes. Limitations include lack of any causal inferences, and thus directionality between the variables which are not fully explored or empirical tested.

Implications: Implications for policymakers encouraging entrepreneurship in SA, are that the complexity of factors involved in enhancing or constraining entrepreneurship should be given due consideration, without any one set of variables overshadowing the other factors. Entrepreneurs, educators, and consultants all benefit from a better understanding of how various factors merge into the intent to start a business. Training entrepreneurs to be aware of the multiple influencing factors will raise their level of sophistication and ability to correctly gauge opportunities.

Originality/Value: Since no unified theme exists regarding the relationship between culture/self/context and entrepreneurship, the synthesis of the variables proposed in this framework offers an introductory roadmap to guide future research. Taking the multiplicity of variables and dimensions influencing entrepreneurial activity even further, the article provides crucial insights of how entrepreneurial outcomes are determined in a SA context; such models are essential for real advances in the emerging field of entrepreneurship.

Key words and phrases: Business regulations, entrepreneurship, culture

\section{INTRODUCTION}

Entrepreneurship is often associated with facilitating national economic growth, creation of new businesses, re-orientation of existing business toward more entrepreneurial goals, and redirection of national institutional infrastructure. There are substantial national consequences for entrepreneurial activity, and as a global phenomenon entrepreneurial activity absorbs a substantial amount of human and financial resources. The existence of a systematic relationship between the per capita GDP of a country, its economic growth and its level of entrepreneurial activity, albeit complex, is intensifying as a result of longitudinal studies such as the Global Entrepreneurship Monitor report (GEM) (Minniti, Bygrave \& Autio, 2005:14). Small and new organisations generate innovations, fill market gaps, and increase competition, consequently promoting economic efficiency. Moreover, there is evidence suggesting that improving the regulatory environment may have positive benefits on the growth and survival of new ventures (Orford, Herrington \& Wood, 2004:39). Not only does the macroeconomic (national economic growth rates) environment together with the more immediate business environment effect the competitiveness and productivity of a country, but more specifically enduring 
national characteristics have been predicted to have an impact on the level of entrepreneurship activity. The formation of entrepreneurial start up ventures is often cited as the most effective way to relocate labour and capital in a transition economy (Luthans, Stajkovic \& Ibrayeva, 2000:98), with recent research among European countries in transition emphasising the point that entrepreneurship exists in every country; this spirit can be fostered with an appropriate framework. If entrepreneurship is not valued in the culture of a particular country then, not only will it be associated with criminality and corruption, but also other forms of economic encouragement will prove ineffective.

Theories of entrepreneurship that have focused on one-sided determinism, where either environmental or personality variables have been specified as unique predictors of entrepreneurship, have failed to capture the complexity of human action that encompasses the interaction of environmental, cognitive, and behavioural variables (Bandura, 1986:18).

The structure of this article is to first clarify the antecedents of venture creation and to conduct literature reviews on the important foundations for those encouraging more entrepreneurship within a cultural context. Secondly, and more specifically, an overview of business regulations which may enhance or constrain new business activity is interrogated. Based on these contemporary models of cultural effects on entrepreneurship, principal findings are identified which bestow new awareness to this stream of entrepreneurship research. Lastly, a framework is proposed to approach the interaction between business context, culture and entrepreneurship more systematically. Such a framework will ultimately fulfil the purpose of this article by integrating various predictors of entrepreneurship into one cohesive framework.

\section{BUSINESS REGULATORY ENVIRONMENT}

The third series of the Worldbank and International Finance Corporation report 'Doing business' (World Bank, 2006), investigates the regulations affecting business activity, with an indicator set used to analyse economic outcomes and identify which reforms have worked, where, and why. This set of quantitative indicators compared across 155 different countries including South Africa (SA) include: starting a business; dealing with licenses; hiring and firing workers; registering property; getting credit; protecting investors; paying taxes; trading across borders; enforcing contracts; and closing a business. South Africa ranks $28^{\text {th }}$ out of the top 30 economies on the ease of doing business, with New Zealand occupying top ranking in terms of having the most business friendly regulations in the world. SA is the only African country to be ranked in the top 30, sharing this enviable position with developed economies (USA, UK, Australia, etc), East Asian countries (Japan, Korea, Malaysia, etc) and emerging Baltic countries (Lithuania, Estonia, and Latvia).

Despite SA's apparent favourable regulatory environment compared with other countries, notwithstanding that indicators are limited in scope, SA's high ranking does not translate into high entrepreneurial activity as it is clear from the series of South African GEM reports (Foxcroft, Wood, Kew, Herrington \& Segal, 2002 and Orford, Wood, Fischer, Herrington \& Segal, 2003); SA has lower than expected Total Entrepreneurship Activity (TEA) rates given its per capita income (Orford, Herrington \& Wood, 2004:50).

In context of discussing institutional obstacles to South African entrepreneurship, Ahwireng-Obeng and Piaray (1999:78), argue that SA is currently drawn in a tide of schizophrenic development (i.e. dual economic system), but that at the level of institutional efficiency, it is just another failing developing country. The political transition has generated policy risks and controversial labour, patent, and competitive legislation together with new taxes and levies that have been passed; the evidence indicates that it is the convergence of institutional risks from crime and security, corruption, and dysfunctional government that poses challenges to entrepreneurs. The experiences of the former Soviet countries demonstrate that during the initial stages of transition to a market economy, entrepreneurship as a source of economic growth is not only unsupported but it is largely neglected and even suppressed. The 'criminalisation' of the economy becomes apparent, in that small business in Russia must depend on private - and often informal or criminal - sources of credit (Luthans et al., 2000:99). A conspicuous parallel to the South African money lending dilemma - with the proliferation of micro lenders in recent years - is evident. Entrepreneurship may in some instances inhibit rather than enhance economic progress, e.g. illegal enterprising and rent seeking activities (Baumol, 
1990:893). Correspondingly, Yu (2000:179), typifies Third World countries as having failed to promote adaptive entrepreneurship; instead these states engage largely in rent seeking activities and exhibit the characteristics of 'vampire states', such as Kenya in the late 1980's whose rulers were described as predatory, i.e. their efforts to maximise the resource flow under their control erodes the ability of the resource base to deliver future flows. Diagrammatically, a model which represents an entrepreneurial model of Hong Kong's economic growth is portrayed in figure 1.

Figure 1: Entrepreneurial model of Hong Kong's economic growth

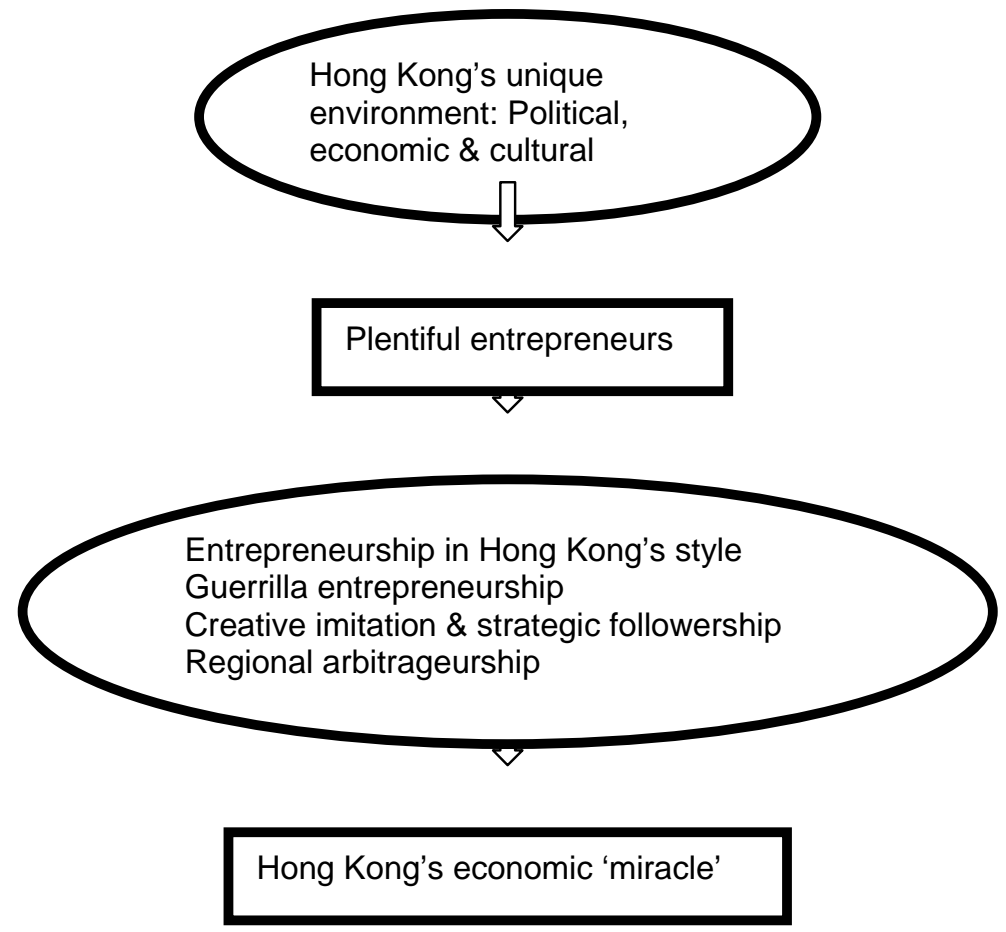

Source: Yu (2000:189)

\section{CULTURE AND ENTREPRENEURSHIP}

A variety of studies lend support to the argument that cultural values influence entrepreneurial behaviour. Much of the study of ethnic entrepreneurs is based on issues of culture, with a growing body of literature supporting the argument that national culture influences a variety of economicl management behaviour (Hofstede, 1980, 2001) and entrepreneurship (McGrath, MacMillan \& Scheinberg, 1992). The aggregate level of entrepreneurial activity is uncertain and heavily influenced by cultural traits, i.e. there is a significant difference among entrepreneurial rates of different groups, which may occur in spite of relatively modest differences among their economic and institutional characteristics. It is acknowledged that substantial variation exists in entrepreneurial activity between countries, with cultural and social norms emphasised as the major strength and weakness of entrepreneurial support structures (Reynolds, Bygrave et al., 2002).

Investigating entrepreneurship in the USA over time, Gartner and Shane (1995:285) suggest entrepreneurship is significantly higher per capita than any other time in the last hundred years; and indeed the USA may be undergoing some fundamental changes in how the economy is organised. It seems the individual is getting in and out of business in greater frequencies as a normal part of their work histories. Some individuals with different cultural roots tend to be more prolific in initiating ventures (Boyd, 1990:54). 
Based on previous research pertaining to culture, the configuration of cultural values for increased entrepreneurship is based on Hofstedes' (1980) dimensions. Hofstede (2001) did not specify the relationship between entrepreneurship and culture; however his dimensions are useful in identifying criteria of culture related to entrepreneurship. The four are labelled as power distance* (PDI), uncertainty avoidance ${ }^{*}$ (UAI), individualism/collectivism* (I-C), masculinity/femininity* (MAS) and a fifth dimension, using a Chinese value survey, is long term/short-term orientation* (LTO) in work ethic (Hofstede \& Bond, 1988). Ceteris paribus, the greater the cultural distance from the ideal type, the lower the level of entrepreneurship (Hayton et al., 2002:39). Hofstedes' $(1980,2001)$ dimensions are widely used for the following reasons: the measures are based on data from 53 developed and developing countries and subsequent studies indicate significant correlations with these dimensions when replicated (Hoppe, 1990 and Sondergaard, 1994). Furthermore, country scores are validated when compared with data from other surveys and indexes measured at country level (e.g. GNP).

More recent analyses of cultural dimensions as conducted by Trompenaar (1993), i.e., achievement vs. ascription, universalism vs. particularism, individualism vs. collectivism, neutral vs. affective, and specific vs. diffuse, suggest that in the different manifestations of culture that national culture occupies the highest level. Correspondingly, some researchers (Rijamampianina \& Maxwell, 2002:18) have proposed that cultural differences may be analysed using a framework that takes into account the extent to which dimensions are core or periphery, visible or invisible.

Cultural values also affect the perception of an individual through cognitive schema, interpretation, and sense making; therefore the dimensions of culture play an important role in shaping an individual schema and sense making which subsequently act as powerful filters that shape interpretation and perception which in turn leads to differences in behaviours and outcomes (Chrisman, Chua \& Steier, 2002). Growth intentions of entrepreneurs in China was tested via a cognitions model, found that not only entrepreneurial commitment, need for achievement, and social environment are important, but that a cognitive understanding of the environment also has a direct impact on growth intentions (Lau \& Busenitz, 2001:30).

Linking values to cognitions means that nearly all other mental programs (such as attitudes and beliefs) carry a value component. Moreover, values tap what is important, beliefs that are true. A finding by Davidsson and Wiklund (1997), that values are more important than beliefs is somewhat surprising, since it is generally concluded in research that more proximal variables i.e., domain specific beliefs, should have higher explanatory power with regard to specific behaviours than have distal variables such as values. When measuring these values it is worth noticing that so many value instruments exist, that a complete review is beyond the aim of this article. Some widely quoted authors on this matter are: Rokeach (1973) and Schwartz (1992), however most of these value models have not been linked to business outcomes.

*Power distance, which is related to the different solutions to the basic problem of human inequality. *Uncertainty avoidance, which is related to the level of stress in a society in the face of an unknown future. *Individualism vs. collectivism, which is related to the integration of individuals into primary groups. *Masculinity vs. femininity, which is related to the division of emotional roles between men and women. *Long term vs. short-term orientation, which is related to the choice of focus for people's efforts: the future or the present (Hofstede, 2001:29).

\section{ENTREPRENEURS AS CATALYSTS OF ECONOMIC ACTIVITY}

New ventures offer the promise of empowering marginalised segments of the population. In researching the relationship between culture and new organisation formation, Davidsson and Wiklund (1997:184), offer two views: firstly, the supportive environment perspective or societal legitimisation perspective, i.e. prevailing values and beliefs among others may make a person more or less inclined towards new venture formation. Secondly, a relationship may occur because some regions have a larger pool of potential entrepreneurs (this view is in accordance with McClelland's (1961); Bygrave and Minniti's (2000); and Thornton's (1999) work, which emphasise the embeddedness of entrepreneurship in social and structural relationships). As a matter of fact, it has been suggested that entrepreneurship is a self-reinforcing process (Bygrave \& Minniti, 2000:30). Entrepreneurship leads to more entrepreneurship and the degree of entrepreneurial activities is an outcome of a dynamic 
process in which social habits (entrepreneurial memory) are as important as legal and economic factors. Thus entrepreneurs act as catalysts of economic activity, and the entrepreneurial history of a community is important. This is relevant since the human capacity to learn by observation (Bandura, 1997) enables entrepreneurs to learn from other model entrepreneurs without having to acquire model behaviours by risky trial and error. Bygrave and Minniti (2000:34) propose that agent's choice is influenced by 'others' chosen paths, and claim that entrepreneurship is hence an interdependent act. Together with threshold models of collective behaviour, indications are that an individual's decision does not depend on his preferences alone but is influenced by what others choose.

Similarly, the view that entrepreneurs act as catalysts resonates with Cooper's and Denner's (1998) perspective - culture as capital; a theory of social capital, which refers to the relationships and networks from which individuals are able to derive institutional support. Social capital is cumulative, leads to benefits in the social world, and can be converted into other forms of capital. Moreover, Lee and Peterson (2000) propose that entrepreneurial orientation (EO), as operationalised by Lumpkin and Dess (1996), serves as a mediator in the relationship between culture and entrepreneurship. They subsequently present a cultural model of entrepreneurship, which suggests that entrepreneurship is more compatible with certain cultures, and a strong EO will ultimately lead to increased entrepreneurship. In an effort to understand the role of an EO and start up culture to enhance economic development in SA, Pretorius and Van Vuuren (2002) conclude that culture in SA is not supportive to the development of an EO. Although empirical evidence is required to substantiate this generalisation, their categorisation of African culture, based on the main cultural dimensions, coincides with other African evaluations, e.g., Kinunda-Rutashobya (1999) and Themba et al. (1999).

Although contemporary research (e.g.Thornton, 1999) has boosted the demand side perspective of entrepreneurship by focusing on the influences exerted by firms and markets, over the last thirty years Weber's (1948) theory of the origin of entrepreneurship as a cultural consequence of individualism has been the meta-theory underlying the dominant supply side perspective in entrepreneurship research.

Studies have tested Weber's thesis relating a protestant work ethic (PWE) to economic success. Paradoxically, individuals in developing countries (mostly non-protestant) tend to average higher on PWE measures than individuals in developed countries. Similarly, other studies have found that many behavioural models include assumptions about capitalism and protestant work ethic that are not applicable in many countries (Jaeger \& Kanungo, 1990). This suggests that the uncritical adoption of western concepts is often not helpful in a culturally different context. Developmental strategies that utilise socio-cultural features of indigenous society may be more desirable. Furthermore, characteristics of developing countries represent overall trends and may not hold for every country on every dimension.

The linkages between cultural dimensions and national wealth, and economic growth of certain cultures, were demonstrated by Hofstede (1980). Similarly, the findings of Johnson and Lenartowicz's (1998) study support a positive relationship between economic freedom and economic growth, with a strong relationship between uncertainty avoidance and economic freedom. However, alternative perspectives exist which maintains that economic freedom is a result, not a cause, of economic growth. The mere presence of cultural values is insufficient to explain economic growth; a nation's economic progress also depends on economic freedom, which seems to be the missing link between culture and economic growth. Conversely, economic freedom may also have a negative effect on a country's level of economic development by increasing income inequality between rich and poor and widening the gap between quality of life in urban and rural areas: both of which seem to have transpired in contemporary SA. Although Hofstede (2001) did demonstrate the link between the individualism/collectivism (I-C) dimension and national wealth of a country, the reverse causality national wealth causing individualism - is more plausible and is statistically supported in the International Business Machines (IBM) case. That is, when a country's wealth increases, its citizens tend to have access to resources, which allows them to do their own thing. However, the negative relationship between individualism and economic growth for the very wealthy countries suggests that this development leads to its own undoing, where wealth has progressed to a level at which most citizens can afford to do their own thing, which leads to friction losses and the national economy grows less. Summing up, wealth provides individualist choices. 
Moreover, at the country level, too much I-C tends to slow economic growth; this notion is reinforced when findings relating entrepreneurship to I-C were investigated by Morris et al. (1994) who found that a balanced level of I-C led to greater entrepreneurship in their multi country sample, including SA. Hence entrepreneurial activity peaks at moderate levels of individualism, with extreme individualism promoting gamesmanship, zero sum competition, and absence of team identification, all lowering levels of entrepreneurship.

The debates in this section clearly indicate that, in addition to individual and cultural differences, forces operating within other larger contexts also determine entrepreneurial activity. Simultaneously, it can be argued that greater attention is needed to document the impact of entrepreneurial processes on the development of human and intellectual capital, since it is apparent that it is not a coincidence that countries that promote entrepreneurial activities are also the most proactive in developing and nurturing their human capital.

\section{ENTREPRENEURSHIP AS INTERACTION BETWEEN PERSONALITY AND CULTURAL VALUES}

Based on cultural theoretical underpinnings, entrepreneurial motivation is likely to be a function of not only culture and personality, but also the interaction between personality and the cultural values. Certain universal principles of motivation seem to cut across cultural borders, the content domain of human needs and motives are universal. Need for enhancement, efficacy, and consistency are universal human characteristics, yet the salience of the various needs as well as the means for satisfying them vary across cultures. Cultural values direct individuals' selective attention to stimuli in the work environment and they serve as criteria for evaluating and interpreting motivational tendencies. In some cultures, people are highly motivated to be unique, whereas in others, people prefer to be like everyone else. For instance, motivation in individualist cultures increases following success, whereas in collectivist cultures, it increases following failure since the individual focuses on how to change the self and improve fit between self - environment (Triandis \& Su, 2002:153).

Scholarly literature on entrepreneurial behaviour, attitudes and intentions is substantial. At the forefront of research are the big five personality dimensions, i.e. risk taking, need for achievement, need for autonomy, locus of control, and self-efficacy (Vecchio, 2003:303). Similarly, cognitive scripts explain a significant amount of variance in venture creation decisions (Mitchell et al., 2000:989); at least some cultural values are related to certain of these scripts, and in some cases, cultural values also moderate the cognition- venture creation decision relationship. Because perceptions and cognitions depend on information that is sampled from the environment and are fundamentally psychological processes, culture-influenced sampled information is important as cultures develop conventions for sampling information (Triandis \& Su, 2002:149).

Through the development of a cognitive model, Busenitz and Lau (1996:25), integrate cognition with social context, cultural values, and personal variables. Their study suggests that some perceptions and beliefs among entrepreneurs transcend cultures. Similarly, Lee and Green's (1990) findings suggest cross-cultural validity of a behavioural intentions model (i.e. the Fishbein model) however, in the study, the founding rates also tend to differ by ethnic groups, and so it is contended that other beliefs and values may be more culture or ethnic group specific.

The cultural self-representation model (see figure 2) developed by Erez and Early (1993), posits that culture manifests itself in an individual's self-identity through basic motives for action. This model proposes that the self in terms of their contribution to self-enhancement, efficacy perceptions, and self-consistency evaluates the potential effectiveness of various management techniques. Cultural norms and standards determine the criteria for evaluation. 
Figure 2: The cultural self-representation model

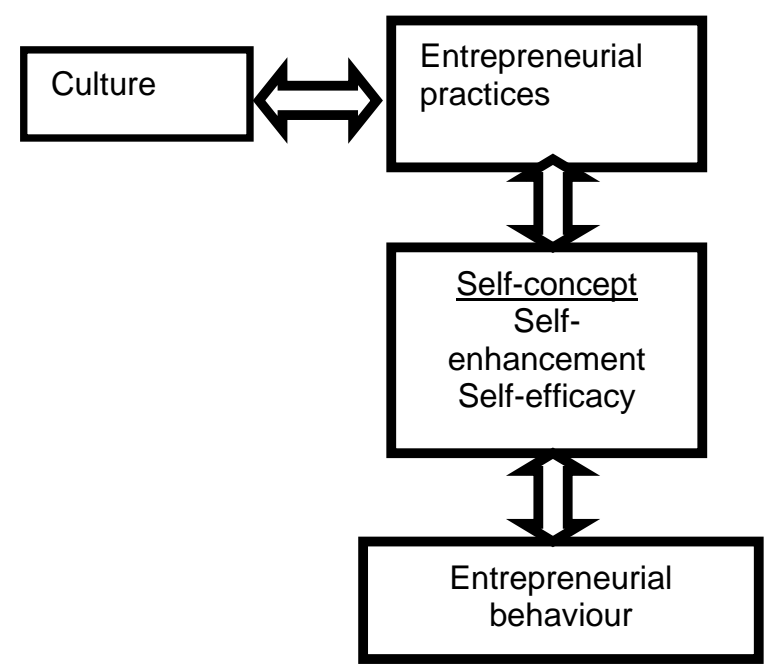

Source: Adapted from Erez and Early (1993:22)

Applied to the South African context, this model could be interpreted as entrepreneurial practices which are likely to be a function of not only culture and self, but also the interaction between self and cultural values. In SA's multicultural context, this becomes increasingly complex where varied cultural influences manifest themselves in a particular setting. This dilemma is further explored in the next sections.

\section{ENTREPRENEURIAL OUTCOMES: ECONOMIC GROWTH AND INNOVATION}

Building on the links between cultural and entrepreneurship research, Tiessen (1997:367) advocates two main streams of research on the effects of Individualism - Collectivism (I-C) on entrepreneurship:

- The micro level stream identifies those who generate variety - founders who tend to be individualistic.

- The macro stream associates both I-C with national level of economic growth and innovation.

Based on the first stream of research and in light of contradictory empirical evidence (i.e. the economic success of several collectivist Asian countries), Tiessen (1997) acknowledges that individualism and collectivism are not negatively related: which allows one to recognise that both orientations can contribute to entrepreneurship. Research portraying average levels of these orientations can obscure the presence of both behaviour types. For instance, Confucian values motivate entrepreneurs in the Asian Tigers to establish and develop businesses in order to provide for their extended families. Similarly, US individualism does not prevent corporations from utilising teams or from forming strategic alliances.

Even though international research conducted at the individual and firm levels lends support that entrepreneurs tend to be individualistic, studies at the national level suggest that both individualism and collectivism are positively associated with entrepreneurial outcomes. It is suggested that these findings differ because micro level research focuses on variety generation (however this focus does not identify proclivities for another entrepreneurial function - leveraging resources, which is very different from variety generation and requires creativity), while macro studies also capture the outcomes of resource leverage (Tiessen, 1997:371). 
Although Africa is largely characterised as a collectivist nation, there is a school of thought that believes that capitalism was practiced in Africa long before colonisation; the amount of cattle possessed was the barometer for measuring an individual's wealth. Whereas a second school of thought argues that socialism has been part of Africa because it is a collectivist society. Factors that have been identified as limiting entrepreneurial activities in sub-Saharan Africa are power distance and collectivism (Takyi-Asiedu, 1993:93).

A concept like Ubuntu (with an element of high community involvement) is in conflict with individualism yet differs from collectivism, where the rights of the individual are subjugated to a common good.

The African version of collective interdependence does not extend as far as the Japanese model where the individual largely ceases to exist, instead individuality is reinforced through community (McFarlin, Coster \& Mogale, 1999). Corder (2001) proposes that individualism and collectivism are poles of a continuum within which African Humanism falls.

Moreover, there has been an emerging emphasis in describing individualism and collectivism in terms of a specific reference group and context rather than society at large. A misconception from this is that collectivism is synonymous with communitarianism and that all collectivists are harmonious and homogeneous (Earley \& Gibson, 1998).

Results from Thomas and Bendixen's (2000) study indicate considerable similarity in values, as measured by Hofstede's (2001) Value Survey Module (VSM94) instrument, across various ethnic groups in SA; they conclude that an effective management culture is independent of ethnic group. A surprising result from their study, when compared to the original Hermes studies (Hofstede, 1980), is the high I-C score, which contradicts many African collectivism theorists. Contradicting Eaton and Louw (2000) in their study of cross cultural differences in self concepts, it was found that African students used a higher proportion of specific and social responses when describing themselves than did English speaking students. This confirms the collectivism assumption and, in general, this type of research illustrates the usefulness and applicability of such theories in the African context. Nonetheless, in many cross-cultural studies, groups are heterogeneous in terms of ethnic, religious, and cultural heritage, and a validated measure of cultural orientation for use with many different cultures in South Africa is required. Moreover, cultural differences may be overrated, and Markoczy (2000:439) postulates that, while culture might influence general values, it does not pervade all aspects of individual beliefs. Shane et al. (1991) demonstrate that there are no universal reasons leading to new business formation across gender and national boundaries. In their three-country survey, out of thirteen factors, only one - freedom to adapt ones own approach to work - can apply across countries and genders.

In two studies using Jackson's Personality Research Form (JPRF), one in Philippines and the other in Zimbabwe, it was noted that ratings on associated trait descriptions for both these countries correlated substantially less with JPRF scores than they typically do with North American data (Church, 2000:651). The possible reasons for this being that respondents in collectivist cultures may find it odd to rate people on global traits without a specification of situational context.

As previously declared, it is important to remember that traits do not predict behaviour as well in collectivist as in individualist cultures. A probabilistic conception is that people in individualist cultures sample mostly internal attributes of self, whereas collectivist cultures sample mostly the collective aspects of self. Correspondingly, Nsamenang (1999) has asserted that knowledge of self may not be considered apart from knowledge of others, since both develop simultaneously through interaction with the social and non-social world. Triandis (2001:908) argues that studies are needed that will untangle the constructs from modernity, affluence, urban status, migration, and exposure to Hollywood.

To confirm the findings so far, cultural values may be a source of competitive advantage for some societies only. This line of thinking is exemplified in a recent study demonstrating the moderating effect of culture on the relationship between entrepreneurial orientation and strategic alliance portfolio extensiveness (Marino et al., 2002), where a firm's ability to leverage its entrepreneurial orientation by 
an extensive strategic alliance portfolio is discouraged primarily by the individualistic aspect of an organisation's national culture.

Moreover, the effect of cultural values can also be seen in a broader sense; if a society does not provide sufficient jobs for certain ethnic groups, for example new immigrants, those ethnic groups that are higher in individualistic values will be more prone to found their own venture. It has also been suggested that local entrepreneurs are socialised in the ways of indigenous populace and thus may display the broad based values of the society in which they live (Steensma, Marino \& Weaver, 2000:592).

In conclusion, it seems much of the work on understanding self-concepts, as they may differ across cultures, makes assumptions without adequate theoretical justification. Early and Gibson (1998) suggest that it is not surprising that the two constructs - individualism vs. collectivism and independent vs. interdependent self-construal - are found to be related. Another problem is that the individual and cultural levels of constructs are not mapped onto one another consistently, suggesting conceptual muddiness. Nonetheless, the reviewed concepts and models allow for clarity and additional insight into how entrepreneurial outcomes are brought about, and these important variables are now consolidated in a framework.

Consolidating these findings, a preliminary framework is proposed which incorporates the diverse results associating context-culture-self-entrepreneurship (see figure 3). Although the components indicate via the arrows a causal effect of cultural dimensions and self on entrepreneurial outcomes, ontological constraints are acknowledged, i.e. the objects of study prevent the ability to 'predict' the complexity of human behaviour in an open environment. In the framework below, selected components (based on established research), are consolidated as being the prime factors leading to entrepreneurial outcomes, which are largely dependant on the prevailing conditions in the broader environment.

Figure 3: Framework of selected components to explain entrepreneurship context from a cultural perspective

\begin{tabular}{|c|c|c|}
\hline $\begin{array}{l}\text { Cultural values } \\
\text { Personal } \\
\text { National } \\
\text { I-C (moderate) } \\
\text { PDI (low) } \\
\text { UAI (low) } \\
\text { MAS (low) } \\
\text { LTO (high) }\end{array}$ & $\begin{array}{l}\text { Beliefs/cognitions/behavior } \\
\text { Big } 5 \text { personality dimensions: } \\
\text { Self-efficacy } \\
\text { Need for achievement } \\
\text { Need for autonomy } \\
\text { Risk taking } \\
\text { Locus of control }\end{array}$ & $\begin{array}{l}\text { Entrepreneurial outcomes } \\
\text { New venture creation } \\
\text { SMME's } \\
\text { Intrapreneurship } \\
\text { Social entrepreneurship } \\
\text { Economic growth }\end{array}$ \\
\hline & $\begin{array}{l}\text { SA entrepreneurial environme } \\
\text { Business regulation (10 indica } \\
\text { Physical and commercial infra } \\
\text { Cooperative institutions - educ } \\
\text { Government policies and supp } \\
\text { Political and macroeconomic }\end{array}$ & $\begin{array}{l}\text { training } \\
\text { ures }\end{array}$ \\
\hline
\end{tabular}

* Worldbank and IFC (2006) report. Based on latest 'Doing business in 2006': Indicator set - starting a business, dealing with licenses, hiring and firing workers, registering property, getting credit, protecting investors, paying taxes, trading across borders, enforcing contracts, closing a business. 


\section{IMPLICATIONS}

Entrepreneurship is an important element in economic growth, in particular for countries under different stages of economic development with varied cultural contexts, such as South Africa. This is relevant insofar that entrepreneurship may in fact be a precondition for country success and survival in a global context.

As part of government's initiatives to foster entrepreneurship, policies should encourage an entrepreneurial culture and mindset, often the cornerstones of entrepreneurship to prevail within a supportive environment. Moreover, specific programs should focus on the interplay between individual entrepreneurs and environmental mechanisms, as is often recommended for developing economies where institutional conditions need to be strengthened first, before entrepreneurship flourishes.

By depicting an integrated framework of entrepreneurship, this has allowed for a broad overview of the potential pattern of relationships between culture, beliefs/cognitions/behaviours and contextual factors to emerge. The implications of this framework suggest that culture and beliefs act as catalysts rather than causal agents of entrepreneurial outcomes. Essentially this means that these antecedents need to be fostered to encourage increased entrepreneurship within a favourable environmental setting.

The theoretical implications of this framework are that it assists researches to examine the relationship between values, cognitions and entrepreneurial outcomes holistically. For some time, entrepreneurship scholars have been searching for constructs of individual characteristics that are unique to entrepreneurs; this overarching framework suggests lack of progress in this direction of research.

Practically, the implications point to several areas of interest to entrepreneurs and policy makers; through demonstrating the complementary nature of selected constructs and their combined explanatory potential in understanding entrepreneurship, focus areas can be identified and fostered to increase entrepreneurship outcomes.

Implications for policymakers encouraging entrepreneurship in SA are that the complexity of factors involved in enhancing or constraining entrepreneurship should be given due consideration, without any one set of variables overshadowing the other factors. Entrepreneurs, educators, and consultants all benefit from better understanding of how various factors merge into the intent to start a business. Training entrepreneurs to be aware of the multiple influencing factors will raise their level of sophistication and ability to correctly gauge opportunities.

\section{CONCLUSION}

This paper set out to provide a broad overview of the potential pattern of relationships between cultural values, personal and contextual factors, and entrepreneurial outcomes. Building on previous conceptualisations and empirical findings, the article identified salient antecedents and consequences of venture creation. Cultural values were linked to the self-concept, cognitions, and personality. The study concedes that, based on the reviewed studies, it appears that no unified theme exists regarding the relationship between culture and entrepreneurship.

Principal findings indicate that, despite SA's apparent favourable regulatory environment, low entrepreneurial activity persists, and understanding the interplay between culture, self, context and entrepreneurship remains imperative for policymakers and practitioners.

On the whole, the diverse findings as presented in this paper regarding the effects of culture at different levels on entrepreneurship, is perhaps best encompassed through the synthesis of theoretical and empirical studies that examine the association between cultural values, cognitions/ beliefs/traits, contextual factors, and entrepreneurial outcomes as depicted in the proposed framework. The synthesis of the variables proposed in this framework offer an introductory roadmap to guide future research. Greater attention is required in future research to focus on theory building 
which encompasses the interaction of contextual, cognitive, and behavioural variables of entrepreneurship.

\section{REFERENCES}

Ahwireng-Obeng F \& Piaray D. 1999. Institutional Obstacles to South African Entrepreneurship. South African Journal of Business Management, 30(3):78-86.

Bandura A. 1997. Self-efficacy. The exercise of control. New York: W.H. Freeman \& Company.

Bandura A. 1986. Social Foundations of Thought and Action. A Social Cognitive Theory. Englewood Cliffs, N.J: Prentice-Hall.

Baumol WJ. 1990. Entrepreneurship: Productive, Unproductive and Destructive. Journal of Political Economy, 98(5):893-921.

Boyd RL. 1990. Black and Asian Self-Employment in Large Metropolitan Areas: A Comparative Analysis. Social Problems, 37(2):54-65.

Busenitz LW \& Lau CM. 1996. A Cross Cultural Cognitive Model of New Venture Creation, Entrepreneurship Theory and Practice, 20(4):25-39.

Bygrave WD \& Minniti M. 2000. The Social Dynamics of Entrepreneurship. Entrepreneurship Theory and Practice, 24(3):25-36.

Chrisman JJ, Chua JH \& Steier PL. 2002. The Influence of National Culture and Family Involvement on Entrepreneurial Perceptions and Performance at the State Level. Entrepreneurship Theory And Practice, Summer:113-130.

Church TA. 2000. Culture And Personality: Toward An Integrated Cultural Trait Psychology. Journal Of Personality, 68(4):651-703.

Cooper RC \& Denner J. 1998. Theories Linking Culture and Psychology: Universal and Community Specific Processes. Annual Review of Psychology, 49:559-84.

Corder CK. 2001. The Identification of a Multi Ethnic South African Typology. D. Phil Thesis. Pretoria: University Of Pretoria.

Davidsson P \& Wiklund J. 1997. Values, Beliefs and Regional Variations in New Firm Formation Rates. Journal of Economic Psychology, 18:179-199.

Earley PC \& Gibson CB. 1998. Taking Stock in Our Progress on Individualism-Collectivism: 100 Years of Solidarity and Community. Journal of Management, 24(3).

Eaton L \& Louw J. 2000. Culture and Self in South Africa: Individualism - Collectivism Predictions. Journal of Social Psychology, 140(2).

Erez M \& Early PC. 1993. Culture, Self Identity, and Work. Oxford: Oxford University Press.

Foxcroft M, Wood E, Kew J, Herrington M \& Segal N. 2002. South African Global Entrepreneurship Monitor Executive Report. Graduate School of Business, UCT.

Gartner WB \& Shane SA. 1995. Measuring Entrepreneurship over Time. Journal of Business Venturing, 10:283-301.

Hayton C, George G \& Zahra SA. 2002. National Culture and Entrepreneurship: A Review of Behavioural Research. Entrepreneurship Theory And Practice, Summer:33-52. 
Hofstede G. 2001. Cultures Consequences. $2^{\text {nd }}$ Ed. Sage Publications. California.

Hofstede G. 1980. Cultures Consequences. Sage Publications. California.

Hofstede G \& Bond MH. 1988. The Confucius Connection: From Cultural Roots to Economic Growth. Organizational Dynamics, 16(4).

Hoppe MH. 1990. A Comparative Study of Country Elites. PhD Thesis. University Of North Carolina.

Jaeger AM \& Kanungo RN. 1990. Management in Developing Countries. London: Routledge.

Johnson JP \& Lenartowicz. 1998. Culture, Freedom And Economic Growth: Do Cultural Values Explain Economic Growth. Journal of World Business, 33 (4).

Kinunda-Rutashobya L. 1999. African Entrepreneurship and Small Business Development: A Conceptual Framework. Eds Kinunda-Rutashobya L \& Olomi DR. African Entrepreneurship and Small Business Development. University Of Dar -Es-Salaam.

Lau CM \& Busenitz LW. 2001.Growth Intentions of Entrepreneurs in a Transitional Economy: The Peoples Republic of China. Entrepreneurship Theory and Practice, 26(1):25-39.

Lee C \& Green RT. 1990. Cross-Cultural Examination of the Fishbein Behavioral Intentions Model. Journal of International Business Studies, September.

Lee SM \& Peterson SJ. 2000. Culture, Entrepreneurial Orientation, and Global Competitiveness. Journal of World Business, 35(4).

Lumpkin GT \& Dess GG. 1996. Clarifying the Entrepreneurial Orientation Construct and Linking It to Performance. Academy Of Management Review, 21(1).

Luthans F, Stajkovic AD \& Ibrayeva E. 2000. Environmental and Psychological Challenges Facing Entrepreneurial Development in Transitional Economies. Journal of World Business, 35(1):95-117.

Marino L, Strandholm KH, Steensma HK \& Weaver MK. 2002. The Moderating Effect of National Culture on the Relationship between Entrepreneurial Orientation and Strategic Alliance Portfolio Extensiveness. Entrepreneurship Theory And Practice, Summer: 145-160.

Markoczy L. 2000. National Culture and Strategic Change in Belief Formation. Journal of International Business Studies, 31(3):427-440.

McClelland DC. 1961. The Achieving Society. New York: Free Press.

McFarlin DB, Coster EA \& Mogale C. 1999. South African Management Development in the Twenty First Century. Journal of Management Development, 18(1):63-78.

McGrath RG, Macmillan IC \& Scheinberg S. 1992. Elitists, Risk Takers, and Rugged Individualists? An Exploratory Analysis of Cultural Differences between Entrepreneurs and Non Entrepreneurs. Journal of Business Venturing, 7:115-135.

Minniti M, Bygrave WD \& Autio E. 2005. Global Entrepreneurship Monitor. Executive report. USA: Babson.

Mitchell RK, Smith JB, Seawright WK \& Morse EA. 2000. Cross Cultural Cognitions and the Venture Creation Decision. Academy of Management Journal, 43(5):974-993.

Morris MH, Davis DL \& Allen JW. 1994. Fostering Corporate Entrepreneurship: Cross-Cultural Comparisons of the Importance of Individualism versus Collectivism. Journal of International Business Studies, 25(1). 
Nsamenang BA. 1999. An Image of Self in African Social Thought. An African Perspective. $2^{\text {nd }}$ ed. Durban: Butterworths.

Orford J, Herrington M \& Wood E. 2004. South African Report, Global Entrepreneurship Monitor. Graduate School of Business, UCT.

Orford J, Wood E, Fischer C, Herrington M \& Segal N. 2003. South African Executive Report Update, Global Entrepreneurship Monitor. Graduate School of Business, UCT.

Pretorius M \& Van Vuuren J. 2002. The Contribution of Support and Incentive Programs to Entrepreneurial Orientation and Start up Culture in South Africa. Presented At South African Entrepreneurship and Small Business Association Conference at Sun City, 4-6 August.

Reynolds PD, Bygrave WD, Autio E, Cox LW \& Hay M. 2002. Global Entrepreneurship Monitor Executive Report. Babson College.

Rijamampianina R \& Maxwell T. 2002. Towards A More Scientific Way of Studying Multicultural Management. South African Journal of Business Management, 33(3):17-26.

Rokeach M. 1973. The Nature of Human Values. New York. Free Press, Macmillan.

Schwartz SH. 1992. Universals in the Content and Structure of Values. Theoretical Advances and Empirical Tests in 20 Countries. Advances in Experimental Social Psychology, 25:1-65.

Shane S, Kolvereid L \& Westhead P. 1991. An Exploratory Examination of the Reasons Leading To New Firm Formation across Country and Gender. Journal of Business Venturing, 6:431-446.

Sondergaard M. 1994. Hofstedes Consequences: A Study of Reviews, Citations and Replications. Organizational Studies, 15(3).

Steensma KH, Marino L \& Weaver MK. 2000. Attitudes toward Cooperative Strategies: A Cross Cultural Analysis of Entrepreneurs. Journal of International Business Studies, 31(4):591-610.

Takyi-Asiedu S. 1993. Some Socio- Cultural Factors Retarding Entrepreneurial Activity in Sub Saharan Africa. Journal of Business Venturing, 8:91-98.

Themba G, Chamme M, Phambuka CA \& Makgosa R. 1999. Impact of Macro- Environmental Factors on Entrepreneurship Development in Developing Countries. Eds: Kinunda- Rutashobya, L., Olomi, D.R .African Entrepreneurship and Small Business Development. University Of Dar -EsSalaam.

Thomas A \& Bendixen M. 2000. The Management Implications of Ethnicity on South Africa. Journal of International Business Studies, 31(3).

Thornton PH. 1999. The Sociology of Entrepreneurship. Annual Review of Sociology, 25:19-46.

Tiessen JH. 1997. Individualism, Collectivism, and Entrepreneurship: A Framework for International Comparative Research. Journal of Business Venturing, 12:367-384.

Triandis HC. 2001. Individualism - Collectivism And Personality. Journal Of Personality, 69:907-924.

Triandis HC \& Su ME. 2002. Cultural Influences on Personality. Annual Review of Psychology, 53:133-160.

Trompenaar F. 1993. Riding the Waves of Culture: Understanding Culture and Diversity in Business. London: Economist Books.

Vecchio RP. 2003. Entrepreneurship and Leadership: Common Trends and Common Threads. 
Human Resource Management Review, 13:303-327.

Weber M. 1948. Essays in Sociology. Translated And Edited By Gerth HH \& Wright Mills C. London: Routledge.

World Bank and the International Finance Corporation. 2006. Doing business in 2006. \# 34550. Washington, D.C.

Yu FT. 2000. Hong Kong's Entrepreneurship: Behaviors and Determinants. Entrepreneurship and Regional Development, 12:179-194. 